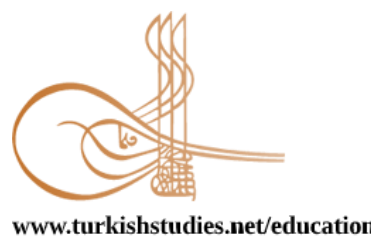

Turkish Studies - Educational Sciences

Research Article / Araştırma Makalesi

\title{
Biyoloji Öğretmen Adaylarının Genel Biyoloji Kavram Anlayışlarını Ölçmek İçin İki Aşamalı Tanı Testi Geliştirilmesi ve Uygulanması
}

\author{
Development and Application of a Two-Tier Diagnostic Test Measuring Prospective Biology \\ Teachers' Understandings of General Biology Concepts
}

\author{
Özge Uzunhasanoğlu* - Mustafa Çakır ${ }^{* *}$ - Süleyman Avcı ${ }^{* * *}$
}

\begin{abstract}
Scientific misconceptions are scientifically incorrect understandings or intuitions that negatively affect the learning and teaching process and are resistant to change. Teachers are one of the most common and important factors that cause students to develop misconceptions. The purpose of this study was to develop and implement a two-tier diagnostic test in order to identify prospective biology teachers' misconceptions and level of understandings of selected general biology concepts. The sample of the study $(\mathrm{N}=296,(235)(79.4 \%)$ females, $62(20.6 \%)$ males)) was consisted of senior biology education students and graduates of biology programs who were enrolled in pedagogical formation programs in five state universities in Turkey. Survey research model within the scope of the quantitative research is used. The final version of two-tier general biology concept diagnostic test consisted of twenty items, measuring understandings in nineteen selected subjects. The average item difficulty index of content information, which is the first tier of items, is 0.39 , and the average item discrimination index is 0.34 . The average item difficulty of the rationale, which is the second tier is 0.28 and the average item discrimination is 0.33 The Cronbach alpha reliability coefficient of the whole test is $r=0.68$. Conceptual understandings of participants were classified based on their answers to test items as conceptual understanding, misconception, memorized knowledge, and inconsistent knowledge. The findings showed that prospective biology teachers have common misconceptions in many general biology subjects that are in the high school curriculum. At least $80 \%$ of the participants had misconceptions in circulatory system, protein synthesis and cell division subjects. The most common misconceptions that are identified in each subject of general biology are discussed in the light of the related literature and suggestions for prospective biology teachers, college biology educators and teacher educators are offered.
\end{abstract}

\footnotetext{
${ }^{*}$ Doktora Öğrencisi, Maltepe Üniversitesi, Lisansüstü Eğitim Enstitüsü, Histoloji ve Embriyoloji Anabilim Dalı Ph. D. Candidate, Maltepe University, Graduate School, Histology and Embriology Program

Cite as/ Atıf: Uzunhasanoğlu, Ö. \& Çakır, M. \& Avcı, S. (2020). Biyoloji öğretmen adaylarının genel biyoloji kavram anlayışlarını ölçmek için iki aşamalı tanı testi geliştirilmesi ve uygulanması. Turkish Studies - Education, 15(4), 24072423. https://dx.doi.org/10.47423/TurkishStudies.44131

Received/Geliş: 09 June/Haziran 2020

Accepted/Kabul: 27 August/Ağustos 2020

Copyright $\subset$ INTAC LTD, Turkey
Checked by plagiarism software

Published/Yayın: 30 August/Ağustos 2020

CC BY-NC 4.0 
Structured Abstract: According to the constructivist learning approach, the concepts that students have an extremely important role in making sense of new knowledge or experiences in learning (Çakır, 2008). Misconceptions are concepts that are not scientifically correct but which students make sense of with naive beliefs, prejudices or their own reasoning (Tekkaya et al., 2000; Nakiboglu, 2006). These are not temporary misrepresentations, but are permanent insights that are resistant to change and compatible with other concepts of the individual. Teachers are one of the most common and important factors in the occurrence of misconceptions. Teachers often have many of the misconceptions students have (Bahar, 2003). The purpose of this study was to develop and implement a valid and reliable two-tier diagnostic test in order to identify prospective biology teachers' misconceptions and level of conceptual understandings of selected general biology subjects.

Theoretical framework: Although misconceptions are mostly realized through informal learning, the school environment in which formal learning takes place is one of the important sources. Among the most important sources of misconceptions are the society in which the individual lives, the family, the circle of friends, the books they read, the textbooks they read and watch on the internet, the teacher and the teaching environment (Malatyali \& Yilmaz, 2010; Gooding \& Metz, 2011; Tekkaya et al., 2000). Teachers are one of the most common and important factors as a source of misconceptions. Excessive generalizations that teachers make during teaching, using old concepts and terms, simplifying teaching more than necessary and using erroneous research results lead to misconceptions (Hershey, 2004). The findings of many studies that determine the misconceptions of prospective biology teachers and teachers are quite worrying (Cokadar, 2012; Krall et al., 2009; Emre \& Bahsi, 2006; Ozcan et al., 2012). The misconceptions that teachers themselves have may lead to the passing of the same misconceptions to the students. Likewise, teachers' lack of knowledge may cause misconception in students (Khalid, 2001; Costu et al., 2007; Tekkaya et al., 2000). Therefore, in order to prevent the progression of this problem, the prospective biology teachers' misconceptions should be diagnosed. Diagnostic tests are useful to reveal misconceptions and facilitate better understanding of general biology among prospective teachers. Recognizing misconceptions in biology teacher candidates can enable curriculum developers and administrators in teacher education to take focused and effective corrective measures by using alternative teaching approaches to misconceptions in teacher candidates (Treagust, 1998). In this study, initially, we developed a two-tier general biology concepts diagnostic test and applied to prospective biology teachers in order to identify their level of conceptual understandings and possible misconceptions. It is necessary for teacher educators to become aware of misconceptions and to learn more about misconceptions of teacher candidates to help eliminate them in teaching methods lessons. The findings of the study can act as a driving force for effective general biology teaching as part of the training of prospective biology teachers.

Method: Initially, development of Two-Tier General Biology Concept Diagnosis Test process started with the study of the misconceptions determined in the field of general biology and the preparation of the statements table. At the end of this process, 25 two-tier items were prepared. Two expert biology educators examined the items for construct and content validity and a language expert examined them for readability and grammar. Test items were revised according to feedbacks from the expert panel. After statistical item and reliability analysis of the test item five items were removed due to psychometrical deficiencies. The final form of the Two-Tier General Biology Concept Diagnosis Test consisted of 20 two-tier items. The sample of the study ( $\mathrm{N}=296$, (235 (79.4\%) females, 62 (20.6\%) males)) was consisted of senior biology education students and graduates of biology programs who were enrolled in pedagogical formation programs in five state universities in Turkey. Survey research model within the scope of the quantitative research is used. When the participants gave the correct answer to both the first and the second tiers of the test, their answers were scored correctly and the participants were considered to have the correct conceptual understanding. If they marked any one of the two tiers incorrectly or selected "I do not know", their answers were scored as wrong. The answers of the participants were coded as "conceptual understanding" if both content and reasoning were correct, "misconception" if both were wrong, "memorized knowledge" if the content is right and the reason was wrong, and "inconsistent knowledge" if the content was wrong and the reason was right.

Findings: Item analysis for the first tiers and the second tiers calculated separately as well as for the whole items and all item difficulty and item discrimination indices were found. In the first content tier, item difficulty values are between 0.16 and 0.81 , and the average item difficulty is 0.39 . The discrimination values of this tier are between 0.03 and 0.66 and the average item discrimination index is 0.34 . The average difficulty

Turkish Studies - Education, 15(4) 
of the items in the second rationale tier is 0.28 and the average discrimination is 0.33 . Finally, the average item difficulty for the whole test is 0.24 and the average item discrimination is 0.35 . The reliability coefficient of the General Biology Concept Diagnostic Test calculated by Cronbach's alpha was 0.68.

Table 1: Difficulty and Discrimination Indices of the First Tiers, Second Tiers, and Whole Items

\begin{tabular}{ccccccc}
\hline Item & \multicolumn{2}{c}{ First Tier } & \multicolumn{2}{c}{ Second Tier } & \multicolumn{2}{c}{ Whole item } \\
\cline { 2 - 7 } & $\mathbf{P j}$ & $\mathbf{r j x}$ & $\mathbf{P j}$ & $\mathbf{\text { jjx }}$ & $\mathbf{P j}$ & $\mathbf{\text { jjx }}$ \\
\hline $\mathbf{1}$ & 0.19 & 0.36 & 0.38 & 0.43 & 0.19 & 0.38 \\
$\mathbf{2}$ & 0.42 & 0.41 & 0.51 & 0.41 & 0.37 & 0.49 \\
$\mathbf{3}$ & 0.41 & 0.43 & 0.14 & 0.26 & 0.14 & 0.26 \\
$\mathbf{4}$ & 0.33 & 0.13 & 0.18 & 0.25 & 0.18 & 0.25 \\
$\mathbf{5}$ & 0.16 & 0.03 & 0.18 & 0.01 & 0.15 & 0.05 \\
$\mathbf{6}$ & 0.53 & 0.49 & 0.51 & 0.56 & 0.49 & 0.58 \\
$\mathbf{7}$ & 0.73 & 0.18 & 0.37 & 0.34 & 0.34 & 0.31 \\
$\mathbf{8}$ & 0.28 & 0.44 & 0.26 & 0.41 & 0.25 & 0.40 \\
$\mathbf{9}$ & 0.56 & 0.40 & 0.26 & 0.19 & 0.23 & 0.24 \\
$\mathbf{1 0}$ & 0.24 & 0.13 & 0.13 & 0.15 & 0.08 & 0.11 \\
$\mathbf{1 1}$ & 0.30 & 0.15 & 0.20 & 0.20 & 0.13 & 0.21 \\
$\mathbf{1 2}$ & 0.16 & 0.26 & 0.17 & 0.19 & 0.12 & 0.24 \\
$\mathbf{1 3}$ & 0.19 & 0.20 & 0.18 & 0.18 & 0.13 & 0.21 \\
$\mathbf{1 4}$ & 0.46 & 0.41 & 0.36 & 0.50 & 0.36 & 0.50 \\
$\mathbf{1 5}$ & 0.54 & 0.66 & 0.48 & 0.65 & 0.43 & 0.73 \\
$\mathbf{1 6}$ & 0.17 & 0.24 & 0.13 & 0.21 & 0.11 & 0.21 \\
$\mathbf{1 7}$ & 0.44 & 0.55 & 0.39 & 0.59 & 0.38 & 0.61 \\
$\mathbf{1 8}$ & 0.81 & 0.33 & 0.49 & 0.60 & 0.46 & 0.64 \\
$\mathbf{1 9}$ & 0.26 & 0.39 & 0.25 & 0.38 & 0.24 & 0.38 \\
$\mathbf{2 0}$ & 0.56 & 0.55 & 0.10 & 0.13 & 0.09 & 0.15 \\
\hline Mean & $\mathbf{0 . 3 9}$ & $\mathbf{0 . 3 4}$ & $\mathbf{0 . 2 8}$ & $\mathbf{0 . 3 3}$ & $\mathbf{0 . 2 4}$ & $\mathbf{0 . 3 5}$
\end{tabular}

According to results, participants have common misconceptions in many general biology subjects. The subjects that prospective teachers have the lowest conceptual understanding are the Reproductive System (6.1\%), Circulatory system $(8.4 \%)$ and Protein synthesis $(9.1 \%)$. The subjects that prospective teachers have the highest conceptual understanding are energy metabolism (50\%), Photosynthesis (42.9\%), Seed germination (38.2\%), Cellular organization $(36.8 \%)$ and Cell respiration $(36 \%, 5)$.

Conclusion and recommendations: General Biology Misconceptions Diagnostic Test developed in this research is a reliable and valid test that can be used to detect misconceptions of prospective biology teachers, biology teachers and the students. A common misconception in biology teacher candidates is related to the effects of reproductive hormones in the human body. Although half of the preservice teachers have content knowledge about the properties of enzymes, they could not determine the correct rationale for the process. Their understanding of replication, transcription and translation processes and their relationship with protein synthesis is also problematic. Only $9.1 \%$ of the participants stated that protein synthesis consists of transcription and translation processes and replication is not related to this process. The prevalence and the frequencies of misconception in prospective teachers, who have received biology content courses for at least four years, require higher education institutions to question quality of education. Higher education institutions should pay special attention to eliminating misconceptions.

Keywords: Biology Education, Misconceptions, Prospective Teachers, Two-Tier Diagnostic Test.

Öz: Fen bilimlerindeki kavram yanılgıları öğrenme ve öğretme sürecini olumsuz etkileyen ve değişime karşı dirençli olan bilimsel olmayan anlayışlardır. Öğretmenler öğrencilerin kavram yanılgıları geliştirmelerine sebep olan en yaygın ve önemli faktörlerden biridir. Bu çalışmada, biyoloji öğretmen adaylarının genel biyoloji konularındaki kavram yanılgılarını teşhis etmek için iki aşamalı tanı testi geliştirilmiş ve katılımcıların genel biyoloji bilgi düzeyleri ve kavram yanılgıları belirlenmiştir. Nicel araştırma modeli kapsamında yer alan tarama modeli kullanılan çalışmanın örneklemi $(\mathrm{N}=296,(235(\% 79,4)$ kadın, $62(\% 20,6)$ erkek) beş devlet üniversitesinde öğrenim gören biyoloji öğretmenliği bölümü son sınıf öğrencileri ve pedagojik formasyon programlarına kayıtlı biyoloji bölümü mezunları oluşturmaktadır. Geliştirilen iki aşamalı kavram tanı testinde on dokuz genel biyoloji konusunda çeşitli anlayışları ölçen toplam yirmi madde bulunmaktadır. Maddelerin 
birinci aşaması olan içerik bilgisinin ortalama madde güçlük indeksi 0,39, ortalama madde ayırt edicilik indeksi ise 0,34 'tür. İkinci aşama olan gerekçe ifadelerinin ortalama madde güçlüğü 0,28 , ortalama madde ayırt ediciliği ise 0,33'tür. Testin Cronbach alfa güvenirlik katsayısı ise $r=0,68$ 'dir. Katılımcıların kavram anlayışları test maddelerine verdikleri cevaplara göre kavramsal anlayış, kavram yanılgısı, ezber bilgi ve tutarsız bilgi olarak sınıflandırılmıştır. Bulgular katılımcıların lise programında yer alan birçok genel biyoloji konusunda oldukça yaygın kavram yanılgılarına sahip olduklarını göstermiştir. Katılımcıların en az \%80'ninde dolaşım sistemi, protein sentezi ve hücre bölünmesi konularında kavram yanılgısı olduğu belirlenmiştir. En sık karşılaşılan kavram yanılgıları alan yazın ışı̆̆ında tartışılmış ve öneriler sunulmuştur.

Anahtar Kelimeler: Biyoloji Eğitimi, Kavram Yanılgıları, Öğretmen Adayları, İki Aşamalı Tanı Testi

\section{Giriş}

Yapılandırmacı öğrenme yaklaşımına göre, öğrencilerin mevcut kavramları öğrenme sırasında yeni bilgileri veya deneyimleri anlamlandırmalarında son derece önemli bir role sahiptir (Çakır, 2008). Kavram yanılgıları, bilimsel olarak doğru olmayan ancak öğrencilerin naif inançları, önyargıları veya kendilerine has bir akıl yürütme ile anlamlaştırdıkları kavramlardır (Tekkaya vd., 2000; Nakiboğlu, 2006). Bunlar geçici yanlış açıklamalar değildir, aksine değişime karşı dirençli ve bireyin diğer kavramları ile uyumlu olan kalıcı anlayışlardır (Bahar, 2003). Kavram yanılgılarının neden oluştuğunu anlamak oluşmalarını engellemek adına daha isabetli çözümler üretilebilir. Bireylerin kavramsal anlayışlarını basit ama etkili teknikler ile değerlendirme ve kavramları tanıma konusundaki araştırmalar faydalı bilgiler sağlayabilir. Hem öğrenci hem de öğretmen ve öğretmen adaylarının belirli biyoloji konularındaki kavram yanılgılarının teşhisi birçok araştırmacı tarafından gerçekleştirilmiştir. Ancak, bu çalışmalar içerik ve kapsam bakımından sınırlıdır (Tekkaya, 2002; Khalid, 2001; Arsal, 2010; Çokadar, 2012; Aş̧̧1 vd., 2001; Krall vd, 2009; Çardak, 2009; Emre ve Bahşi, 2006). Bu tür çalışmalar sadece biyolojide belirli bir konuya odaklandığından, çok çeşitli genel biyoloji kavramları için de kavram teşhis ve tanı araçlarının geliştirilmesi hala gereklidir. Fen bilimleri eğitiminde bilişsel yapıya yönelik araştırmalar her zaman önemli olmuştur.

Kavram yanılgıları bireyin hayatının her aşamasında ortaya çıkar. Kavram yanılgıların en çok informal öğrenme yoluyla gerçekleşmesine rağmen, formal öğrenmenin gerçekleştiği okul ortamı da önemli kaynaklardan birisidir. Kavram yanılgılarının en önemli kaynakları arasında bireyin içinde yaşadığ 1 toplum, aile, arkadaş çevresi, okuduğu kitaplar, internet ortamında okudukları ve izledikleri, ders kitapları, öğretmen ve öğretim ortamı sayılabilir (Malatyalı ve Yılmaz, 2010; Gooding ve Metz, 2011; Tekkaya vd., 2000). Öğretmenler kavram yanılgılarının oluşmasında en yaygın ve önemli faktörlerden biridir. Öğretmenler çoğu zaman öğrencilerin sahip oldukları kavram yanılgılarının birçoğuna sahiptir (Bahar, 2003). Öğretmenlerin öğretim sırasında yaptıkları, aşırı genellemeler, eski kavramları ve terimleri kullanmaları, öğretimin gereğinden fazla basitleştirilmesi ve hatalı araştırma sonuçlarını kullanmaları kavram yanılgılarına yol açar (Hershey, 2004). Öğretmenler ve öğretmen adaylarının biyoloji alanındaki kavram yanılgılarını tespit eden çok sayıdaki araştırmanın sonuçları, oldukça endişe vericidir (Çokadar, 2012; Krall vd., 2009; Emre ve Bahşi, 2006; Özcan vd., 2012). Öğretmenlerin kendilerinin sahip olduğu kavram yanılgıları, aynı yanılgıların öğrencilere geçmesine yol açar. Aynı şekilde, öğretmenlerin temel bilgilerdeki eksiklikleri de öğrencilerde kavram yanılgısına sebep olabilir (Khalid, 2001; Coştu vd., 2007; Tekkaya vd., 2000). Bu durumda, bu sorunun ilerlemesini önlemek için biyoloji öğretmen adaylarının genel biyoloji kavram yanılgılarının teşhis edilmesi gerekir. Bu nedenle, bu araştırmada biyoloji öğretmen adaylarının önemli genel biyoloji kavram anlayışlarını belirlemeye yönelik iki aşamalı teşhis testi geliştirilmiştir. Öğretmen eğitimcilerinin kavram yanılgılarının farkına varmaları ve öğretim yöntemleri derslerinde bunları ortadan kaldırmaya yardımcı olmak için öğretmen adaylarının kavram yanılgıları hakkında daha fazla bilgiye sahip olmaları gereklidir. 
Genel biyoloji hücresel organizasyon, canlılarda enerji dönüşümleri, canlıların çeşitliliği, kalıtım ve ekosistem konuları gibi temel yaşam süreçlerinin anlaşılmasını içerir. Öğrenme önceki bilgiler üzerine inşa edildiği için yanlış bir kavram sonraki öğrenmelerin yanlış olmasına yol açar. Özellikle fen eğitiminde öğrencilerin kavram yanılgıları, sebepleri ve nasıl düzeltilecekleri önemli bir çalışma alanıdır (Çakır, 2008). Özcan vd. (2012) biyoloji öğretmen adaylarında mitoz ve mayoz bölünme konusunda çok sayıda kavram yanılgısı tespit etmiştir. Kurt (2013) biyoloji öğretmen adaylarında enzimler konusunda çok sayıda kavram yanılgısı belirlemiştir. Pelaez vd. (2005) öğretmen adaylarının dolaşım sistemiyle ilgili kanın nasıl dolaştığı, damarlar arasındaki geçiş, gaz değişiminin nasıl olduğu, karbondioksitin nasıl üretildiği ve akciğerin işlevleriyle ilgili kavram yanılgılarına sahip olduklarını tespit etmiştir. Krall vd. (2009) çalışmalarında öğretmenlerin sadece yüzde 25 'inin bitkilerin ışık olmadan da solunum yaptığını bildiği ortaya çıkarmıştır. Öğrencilerin fotosentez ve solunum (Çokadar, 2012; Aşçı vd., 2001), canlıların sınıflandırılması (Naz ve Nasreen, 2013), osmoz ve difüzyon (Koyuncuer, 2014; Odom 1995), hücre (Ecevit ve Şimşek, 2017; Kete vd., 2012), mitoz ve mayoz bölünme (Atılboz, 2004; Kara, 2007), kalıtım (Aydın ve Balım, 2013; Çakır ve Aldemir, 2011), enzimler (Kurt, 2013; Bretz ve Linenberger, 2012; Selvi ve Yakışan, 2004) ve sistemler (Özgür, 2013; Pelaez vd., 2005) dâhil olmak üzere genel biyolojinin belirli konularındaki kavram yanılgıları araştırmalara konu olmuştur. Öğretmenlerin bazen bilgi aktarıcısı bazen bilgi buldurucusu rolünü oynadığı eğitim ve öğretim ortamında bilimsel olarak doğru bilgilerle donanmış olmaları gerekir. Kendisi kavram yanılgısına sahip bir öğretmenin kavram yanılgısını tespit etmesi ve düzeltmesi mümkün olmayacaktır. Bu durumda öğretmenler yanlış kavramların öğrencilere aktarılmasına veya yeni kavram yanılgılarının ortaya çıkmasına yol açacaktır.

Kavram yanılgıları, çoktan seçmeli testler, iki aşamalı testler, kavram haritaları, kelime ilişkilendirme testleri, açık uçlu sınavlar ve görüşme yollarıyla tespit edilebilir (Riche, 2000). Çoktan seçmeli testler, mevcut kavram yanılgılarının tespit edilmesini güçleştirir. Ayrıca çeldiricilerde hatalı bilgilerin verilmesi durumunda, öğrenciler bu yanlışları öğrenebilir. Ecevit ve Şimşek (2017) tarafından yapılan bir çalışmada, öğretmenlerin öğrencilerin kavram yanılgılarını çoğunlukla öğrencilerin ders içerisindeki sözel ve yazılı ifadelerinden anladıklarını tespit etmiş̧ir. Bunun yanında öğretmenler öğretim etkinlikleri sırasında da kavram yanılgılarını anladıklarını belirtmişlerdir (Tekkaya, 2002). Çoktan seçmeli testlerde, verilen cevabın gerekçesini öğrenmenin imkânı yoktur (Turgut ve Baykul, 2015). Bununla birlikte, iki aşamalı çoktan seçmeli testlerin kavram yanılgılarını teşhis etmek için daha avantajlı özellikleri vardır (Çakır ve Aldemir, 2011). Büyük örneklemlerde kullanılmaya uygun olmanın yanı sıra analiz edilmesi nispeten kolaydır ve daha geniş bulguların yaygınlaştırılmasına izin verir. Ayrıca, katılımcı anlayışları hakkında daha çok ve net fikir verirler. Treagust (1998) tarafindan geliştirilen iki aşamalı bir testte, her madde bir kavramla ilgili iki çoktan seçmeli sorudan oluşur. İlk aşama bir içerik yanıtı gerektirirken, ikinci aşama ilk yanıt için bir gerekçe gerektirir. Her maddenin ikinci aşaması, birinci aşamadan gelen cevaplar için bir dizi açılamadan oluşabilir. Bu ikinci aşamanın amacı öğrencilerin anlayışları hakkında derinlemesine bilgi sağlamak ve aynı zamanda varsa kavram yanılgılarını ortaya çıkarmaktır. Bu test kavram yanılgısını tespit etmede oldukça yaygın olarak kullanılır (Kaya, 2010). Bernhisel (1999) öğretmen adaylarının kavram yanılgılarını belirlemek amacıyla iki aşamalı test kullanılmıştır. Tunç vd. (2011) öğretmen adaylarının kavramlarını ölçmek için geliştirdikleri iki aşamalı teste, üçüncü aşama olarak verdikleri cevaplardan emin olup olmadıkları seçeneğini eklemişlerdir. Eğer ilk iki aşamada öğretmen adayı kavram yanılgısını içeren seçenekleri işaretledi ve üçüncü aşamada emin olduğunu belirtmişse kavram yanılgısını var olduğu sonucuna ulaşmışlardır. Kavram yanılgılarının belirlenmesinde gerekçe önemlidir. Gerekçe bilinmediğinde, yanlış cevabın kavram yanılgısından $\mathrm{m}$ 1 yoksa sadece cevabı bilmemek veya yanlış bilmekten mi kaynaklandığ tespit edilemez.

Tanı testleri kavram yanılgılarını ortaya çıkarmak ve öğretmen adayları arasında genel biyolojinin daha iyi anlaşılmasını kolaylaştırmak için yararlıdır. Biyoloji öğretmen adaylarındaki 
kavram yanılgılarının farkına varılması, öğretmen eğitimindeki öğretim programı geliştiricilerinin ve yöneticilerinin öğretmen adaylarındaki kavram yanılgılarına yönelik alternatif öğretim yaklaşımlarını kullanarak odaklı ve etkili düzeltici önlemler almalarını sağlayabilir (Treagust, 1998). $\mathrm{Bu}$ çalışmanın temel amacı, biyoloji öğretmen adaylarının genel biyoloji konularındaki kavram yanılgılarını teşhis etmek için geçerli ve güvenilir iki aşamalı tanı testi geliştirmek ve katılımcıların genel biyoloji bilgi düzeyleri ve kavram yanılgılarını belirlemektir. Çalışmanın bulguları biyoloji öğretmen adaylarının eğitiminin bir parçası olarak etkili genel biyoloji öğretimi için bir itici güç olarak işlev görebilir.

\section{Yöntem}

Biyoloji öğretmen adaylarının genel biyoloji konusundaki bilgi düzeylerinin ve kavram yanılgılarının belirlenmesini amaçlayan bu çalışmada nicel araştırma modeli kapsamında yer alan tarama modeli kullanılmıştır. Tarama modeli, bir olayı, durumu, değişkeni olduğu haliyle belirli bir zaman diliminde tanımlamaya yarayan araştırma yaklaşımıdır (Büyüköztürk vd., 2016). Çalışma kapsamında iki aşamalı Genel Biyoloji Kavram Tanı Testi geliştirilmiştir. İki aşamalı test geliştirme süreci genel biyoloji konularında alan yazında tespit edilmiş kavram yanılgılarının incelenmesi ve belirtke tablosu hazırlanması ile başlanmıştır. İki aşamalı testlerin ilk aşaması için çoktan seçmeli sorular ikinci aşaması için verilen cevabın sebebi niteliğinde açıklamalar hazırlanmıştır. Bu sorular iki biyoloji eğitimcisi öğretim üyesi ve bir dil uzmanı tarafından incelenmiş ve maddeler revize edilmiştir. Test geliştirme süreci ile ilgili detaylar ayrı bir alt başlık altında aşağıda açıklamıştır.

\section{Örneklem}

Çalışmanın örneklemini Türkiye'deki 5 devlet üniversitesinde (Marmara Üniversitesi, Dicle Üniversitesi, Karadeniz Teknik Üniversitesi, Atatürk Üniversitesi, Yüzüncü Y1l Üniversitesi) öğrenim gören biyoloji öğretmenliği bölümü son sınıf öğrencileri ve bu üniversitelerde yürütülen pedagojik formasyon programlarına kayıtlı Fen Edebiyat Fakültesi biyoloji bölümü mezunlarından oluşmaktadır. Çalışma kapsamında toplam $296(235$ kadın $(\% 79,4), 62$ erkek $(\% 20,6))$ öğretmen adayına ulaşılmıştır. Katılımcıların cinsiyet mezuniyet durumları Tablo 1'de verilmiştir.

Tablo 1: Örneklemin Demografik Özellikleri

\begin{tabular}{llcc}
\hline & & $\mathbf{N}$ & $\mathbf{\%}$ \\
\hline \multirow{2}{*}{ Cinsiyet } & \multicolumn{1}{l}{ Kadın } & 235 & 79.4 \\
\cline { 2 - 4 } Erkek & 62 & 20.6 \\
\hline \multirow{2}{*}{ Bölüm } & $\begin{array}{l}\text { Biyoloji Öğretmenliği } \\
\text { (Son sınıf) }\end{array}$ & 57 & 19.3 \\
\cline { 2 - 4 } & $\begin{array}{l}\text { Biyoloji Bölümü (Son } \\
\text { sinıf) }\end{array}$ & 41 & 13.9 \\
\hline $\begin{array}{l}\text { Biyoloji } \\
\text { (Mezun) }\end{array}$ & Bölümü & 198 & 66.9 \\
\hline Toplam & & 296 & 100 \\
\hline
\end{tabular}

\section{Veri Toplama aracı}

Araştırma kapsamında geliştirilen "Genel Biyoloji Kavram Tanı Testi” yirmi iki aşamalı sorudan oluşmaktadır. Soruların birinci bölümlerinde "bilmiyorum" seçeneği hariç, üç tane iki seçenekli, üç tane üç seçenekli ve on dört tane dört seçenekli soru bulunmaktadır. Soruların tamamının ikinci aşaması "bilmiyorum" seçeneği hariç dört seçeneklidir. Ölçme aracında beş solunum ve fotosentez, dört sistemler, dört hücre, iki kalıtım, bir enzimler, iki canlıların sınıflandırması ve iki canlıların temel bileşenleri konularında sorular vardır. Katılımcıların ancak bir 
sorunun iki aşamasına da doğru cevap verdiklerinde bilimsel olarak doğru kavramlara sahip oldukları kabul edilir. Bunun dışındaki cevaplar nitelik olarak değerlendirilir ve katılımcının konuyu bilmediğinden dolayı mı yoksa kavram yanılgısından dolayı $\mathrm{m}$ yanlış cevap verdiğine karar verilir.

\section{İki Aşamalı Genel Biyoloji Kavram Tanı Testinin Geliştirilmesi}

Biyoloji kavram yanılgılarını değerlendirmek için iki aşamalı Genel Biyoloji Kavram Tanı Testinin geliştirilmesinde Chandrasegaran vd. (2007) tarafindan önerilen, üç aşamada özetlenen ve aşağıda açıklanan toplam altı adım izlenmiştir (Tablo 2). Adım 1: Ortaöğretim biyoloji öğretmenlerinin sahip olması gereken biyoloji kavramlarının belirlenmesi. Kavramlar Milli Eğitim Bakanlığının mevcut Biyoloji Ders Programı kazanımlarının incelemesi ile yazarlar tarafindan belirlenmiştir. Biyoloji kavramlarının bilgi alanları ve bir veya daha fazla kazanım ile ilgili olup olmadıkları dikkate alınmıştır. Adım 2: Alan yazında rapor edilen biyoloji kavram yanılgılarının incelenmesi. Daha önce de belirtildiği gibi, her yaştan ve eğitim seviyesinden bireylerde biyolojinin birçok alanındaki kavramlar ile ilgili çok sayıda kavram yanılgısı olduğu bilinmektedir (Naz ve Nasreen, 2013; Tunç vd., 2011). Ancak araştırmaların büyük çoğunluğu öğrencilerin kavram yanılgılarına odaklanmıştır. Kavram yanılgılarının yaygın, istikrarlı ve değişime genellikle dirençli olduğu gösterildiğinden (Özgür, 2013), öğretmenler de alan yazında öğrencilerin sahip oldukları gösterilen bazı biyoloji kavram yanılgılarına sahip olabilirler. Bu nedenle alan yazındaki biyoloji kavram yanılgıları toplanmıştır. Adım 3: MEB Biyoloji programında belirtilen kazanımların öğretimi sırasında biyoloji öğretmenleri tarafından öğrencilere verilmesi muhtemel olan kavram yanılgılarının seçilmesi. Biyoloji öğretmenleri biyoloji ile ilgili pek çok kavram yanılgısına sahip olabilirler. Ancak bu çalışmada lise biyoloji programındaki kazanımların öğretimini zorlaştırabilecek kavram yanılgılarına odaklanılmıştır. Adım 4: Genel Biyoloji Kavram Yanılgıları Tanı Testi'nin ilk taslağını geliştirmek. Test maddelerinin yazım sürecinde alan yazından seçilmiş soruların yanı sıra yazarlar tarafından üretilen maddeler ile birlikte toplam 25 iki aşamalı çoktan seçmeli test maddesi geliştirilmiştir. $\mathrm{Bu}$ test maddeleri biyoloji öğretmen adaylarının seçilmiş biyolojik kavram anlayışlarını değerlendirmek için tasarlanmıştır. Her madde, bilimsel olarak kabul edilen bir ifade ve yanlış kavramları veya bir biyoloji kavramının eksik anlaşılmasını temsil eden birkaç ifade dâhil olmak üzere olası seçim için çeşitli seçenekler içermektedir. Adım 5: Test maddelerinin ilgili anlayışları doğru temsil ettiklerinin doğrulanması. Test maddelerinin bilimsel içerikleri uzman iki biyoloji profesörü tarafından incelenmiştir. Uzmanların geri bildirimleri dikkate alınarak Genel Biyoloji Kavram Yanılgıları Tanı Testi'nin ilk taslağındaki iki madde tamamen değiştirilmiş ve diğer üç madde ölçeğin geçerliliğini artırmak için revize edilmiştir. Tanı testinin doğru bir şekilde anlaşılmasını kolaylaştırmak için test maddelerinin ifadeleri bir eğitim psikolojisi uzmanı ve bir dil uzmanı tarafından sağlanan geri bildirimlere göre gözden geçirilmiştir. Adım 6: Genel Biyoloji Kavram Yanılgıları Tanı Testi'nin pilot çalışmasının yapılması. Ölçme aracı yirmi aday biyoloji öğretmenine uygulanmış ve her katılımcı ile görüşmeler yapılarak test maddeleri hakkındaki fikirleri alınarak ölçeğin nasıl daha anlaşılabilir olabileceği ile ilgili bilgi toplanmıştır. Pilot uygulamadaki biyoloji öğretmen adayları tarafından sağlanan bilgilere dayanarak, test öğelerinin daha anlaşılır hale getirilmesi amacıyla çeşitli maddelerin ifadelerinde bazı değişiklikler yapılmıştır. 
Tablo 2: İki Aşamalı Test Geliştirme Süreci

\begin{tabular}{|c|c|}
\hline 1. Aşama: İçeriğin Belirlenmesi & $\begin{array}{l}\text { - Konu başlıklarının tanımlanması } \\
\text { - Konuyla ilgili önermelerin belirlenmesi } \\
\text { - Kapsam haritasının geliştirilmesi }\end{array}$ \\
\hline $\begin{array}{l}\text { 2. Aşama: Öğrencilerin kavram } \\
\text { yanılgılarıla ilgili bilgi } \\
\text { toplanması }\end{array}$ & $\begin{array}{l}\text {-İlgili literatürün taranması } \\
\text {-Çeşitli görüşmelerle öğrencilerin kavram yanılgılarının belirlenmesi } \\
\text {-Öğrencilerin kavram yanılgılarının çoktan seçmeli testlerle alınması } \\
\text {-Yarı yapılandırılmış öğrenci görüşmeleri }\end{array}$ \\
\hline $\begin{array}{l}\text { 3. Aşama: İki aşamalı testin } \\
\text { geliştirilmesi }\end{array}$ & $\begin{array}{l}\text { Testin geliştirilmesi } \\
\text { Dönüt ve Düzeltmelerin Yapılması } \\
\text { Teste son halinin verilmesi }\end{array}$ \\
\hline
\end{tabular}

Tablo 2'de özetlenen sürecin ilk aşamasında bilimsel bilgiler, ikici aşamasında ise bu bilimsel bilgilerin alternatifi olan kavram yanılgıları toplanmıştır. Üçüncü Aşamada ise soruların yazılması işlemi gerçekleştirilmiştir. Bu süreç sonunda 25 iki aşamalı soru hazırlanmıştır. Sorular üzerinde yapılan uzman değerlendirmeleri sonucu, kapsam geçerliği de dikkate alınarak beş soru çıkarılmıştır. Nihayetinde uygulama için 20 soru hazırlanmıştır. Soruların madde analizi ve güvenirlik analizine ilişkin istatistiki çalışmalar aşağıda ayrı başlık altında ele alınmıştır. Geliştirilen sorulara ilişkin belirtke tablosu aşağıda yer almaktadır.

\section{Verilerin analizi}

Katılımcılar testin hem birinci hem de ikinci aşamasına doğru cevabı verdiklerinde cevapları doğru olarak puanlanmış ve katılımcıların doğru kavramsal anlayışa sahip oldukları kabul edilmiştir. İki aşamadan herhangi birisini yanlış işaretlemeleri veya bilmiyorum seçeneğini seçmeleri durumunda cevapları yanlış olarak puanlanmıştır. Katılımcıların cevapları, içerik bilgisi ve gerekçe bölümlerinin ikisinde de doğru ise "kavramsal anlayış", her ikisi de yanlış ise "kavram yanılgısı", içerik bilgisi doğru gerekçe yanlış ise "ezber bilgi" ve içerik bilgisi yanlış gerekçe doğru ise "tutarsız bilgi" olarak kodlanmıştır (Tablo 3). Kavramsal anlayış öğretmen adaylarının konuyu anlamlı düzeyde öğrendiğini, kavram yanılgısı ise ilgili konuda kavram yanılgısına sahip olduğunu göstermektedir. Ezber bilgi konunun gerekçesine hâkim olunmadan ezberlendiği, tutarsız bilgi ise gerekçe ile içerik bilgisinin eşleştirilemediğini ifade etmektedir.

Tablo 3: Maddeleri Puanlama ve Yorumlama Cetveli

\begin{tabular}{lcccl}
\hline \multirow{2}{*}{ Puan } & \multicolumn{2}{c}{ Yanıt } & \multicolumn{1}{c}{ Yorum } \\
\cline { 2 - 4 } & İçerik Bilgisi & Gerekçe & \\
\hline 1 & $\checkmark$ & $\checkmark$ & Kavramsal Anlayış \\
\hline 2 & $\times$ & $\times$ & Kavram Yanılgısı \\
\hline 3 & $\checkmark$ & $\times$ & Ezber Bilgi \\
\hline 4 & $\times$ & $\checkmark$ & Tutarsız Bilgi \\
\hline
\end{tabular}

Katılımcıların testteki 20 sorunun her bir bölümü için tercih ettikleri seçenekler kaydedilmiştir. Test maddeleri verideki desenleri ve test maddelerinde yanlış cevapların türlerini ve sıklığını belirlemek amacıyla Tablo 3 'te verilen cetvele göre puanlanmış ve yorumlanmıştır. Bir test maddesi katılımcıların ancak her iki aşamada da doğru seçeneği tercih ettikleri durumda doğru olarak puanlanmıştır. Madde güçlük ve madde ayırt edicilik değerleri hesaplanmıştır. Ölçme aracının dış güvenirliği eşdeğer yarılar, iç güvenirliği ise Cronbach alfa ile analiz edilmiştir. Ölçek maddelerine verilen cevapların betimleyici istatistikleri olarak sıklık dağılımı için yüzde ve frekans değerleri hesaplanmıştır. 


\section{Bulgular}

İki aşamalı genel biyoloji kavram tanı testinin geliştirilmesi sürecindeki analiz kapsamında madde güçlük ve ayırt edicilik değerleri hesaplanmıştır. Test maddelerinin her birinin ilk aşaması ve ikinci aşaması için madde istatistikleri ayrı ayrı incelendikten sonra maddenin tümü için ayrıca hesaplama yapılmış ve tüm indeks değerleri Tablo 4'te verilmiştir. İçerik bilgisi bölümünde madde güçlük değerleri 0,16 ile 0,81 arasında olup ortalama madde güçlüğü 0,39 'dur. Bu bölüme ait ayırt edicilik değerleri ise 0,03 ile 0,66 arasında olup ortalama madde ayırt edicilik değeri 0,34 'tür. Gerekçe boyutunda maddelerin ortalama güçlüğü 0,28 ortalama ayırt ediciliği ise 0,33 'tür. Son olarak sonuç için ortalama güçlük 0,24 ortalama ayırt edicilik ise $0,35^{\prime}$ tir. Madde güçlügüu için ölçütler geliştirilen testin amacına göre değişiklik gösterir. Seçme sınavlarında zor $(<0,40)$, okul sinavlarında orta güçlükte $(0,40-0,60$ arası) sorular seçilmelidir (Baykul, 2015). Bu çalışmada öğretmen adaylarının kavram yanılgıları tespit edildiğinden soruların öğrenciler için kısmen zor geldiği güçlük değerlerinden anlaşılmaktadır. Madde ayırt edicilik için değerin en azından 0,19 üzerinde olması gerekmektedir (Baykul, 2015). Bu çalışmada içerik bilgisi bölümünde beş, gerekçe boyutunda dört ve sonuç için üç maddenin ayırt edicilik değerleri 0,19 altındadır. Bu sonucun zor sorulardan kaynaklandığı anlaşılmaktadır. Testin amacının kavram yanılgılarını tespit etmek olması nedeniyle ulaşılan değerler beklenen bir durumdur. Bu nedenle sorular olduğu şekliyle alınmıştır. $\mathrm{Bu}$ kararda ortalama madde ayırt edicilik değerinin yüksek olması da belirleyici olmuştur.

Tablo 4: Maddelerin Birinci ve İkinci Aşamalarına ve Tümüne Ait İstatistikler

\begin{tabular}{ccccccc}
\hline Madde & \multicolumn{2}{c}{ İlk Aşama } & \multicolumn{2}{c}{ İkinci Aşama } & \multicolumn{2}{c}{ Tüm Madde } \\
\cline { 2 - 7 } & $\mathbf{P j}$ & $\mathbf{r j x}$ & $\mathbf{P j}$ & $\mathbf{r j x}$ & $\mathbf{P j}$ & $\mathbf{r j x}$ \\
\hline $\mathbf{1}$ & 0.19 & 0.36 & 0.38 & 0.43 & 0.19 & 0.38 \\
$\mathbf{3}$ & 0.42 & 0.41 & 0.51 & 0.41 & 0.37 & 0.49 \\
$\mathbf{4}$ & 0.41 & 0.43 & 0.14 & 0.26 & 0.14 & 0.26 \\
$\mathbf{5}$ & 0.33 & 0.13 & 0.18 & 0.25 & 0.18 & 0.25 \\
$\mathbf{6}$ & 0.16 & 0.03 & 0.18 & 0.01 & 0.15 & 0.05 \\
$\mathbf{7}$ & 0.53 & 0.49 & 0.51 & 0.56 & 0.49 & 0.58 \\
$\mathbf{8}$ & 0.73 & 0.18 & 0.37 & 0.34 & 0.34 & 0.31 \\
$\mathbf{9}$ & 0.28 & 0.44 & 0.26 & 0.41 & 0.25 & 0.40 \\
$\mathbf{1 0}$ & 0.56 & 0.40 & 0.26 & 0.19 & 0.23 & 0.24 \\
$\mathbf{1 1}$ & 0.24 & 0.13 & 0.13 & 0.15 & 0.08 & 0.11 \\
$\mathbf{1 2}$ & 0.30 & 0.15 & 0.20 & 0.20 & 0.13 & 0.21 \\
$\mathbf{1 3}$ & 0.16 & 0.26 & 0.17 & 0.19 & 0.12 & 0.24 \\
$\mathbf{1 4}$ & 0.19 & 0.20 & 0.18 & 0.18 & 0.13 & 0.21 \\
$\mathbf{1 5}$ & 0.46 & 0.41 & 0.36 & 0.50 & 0.36 & 0.50 \\
$\mathbf{1 6}$ & 0.54 & 0.66 & 0.48 & 0.65 & 0.43 & 0.73 \\
$\mathbf{1 7}$ & 0.17 & 0.24 & 0.13 & 0.21 & 0.11 & 0.21 \\
$\mathbf{1 8}$ & 0.44 & 0.55 & 0.39 & 0.59 & 0.38 & 0.61 \\
$\mathbf{1 9}$ & 0.81 & 0.33 & 0.49 & 0.60 & 0.46 & 0.64 \\
$\mathbf{2 0}$ & 0.26 & 0.39 & 0.25 & 0.38 & 0.24 & 0.38 \\
\hline Ortalama & 0.56 & 0.55 & 0.10 & 0.13 & 0.09 & 0.15 \\
\hline
\end{tabular}

Genel Biyoloji Kavram Anlayışları Tanı Testi'nin eşdeğer yarılar tekniğiyle hesaplanan güvenirlik katsayıs1 0,63 , Cronbach alfa ile hesaplanan güvenirlik katsayıs1 ise 0,68 olarak tespit edilmiştir. Nunally (1978) çoktan seçmeli bilgi testlerinde güvenirlik değerinin 0,50 ve üzeri olması gerektiğini belirtmiştir. Elde edilen her iki değerin de alt sınır olan 0,50 'den oldukça yüksek olması ölçme aracının güvenilir olduğunu göstermektedir. 
İki aşamalı Genel Biyoloji Kavram Anlayışları Tanı Testi maddelerinin konu içerikleri ve biyoloji öğretmen adaylarında bu konularda gözlenen kavramsal anlayış, kavram yanılgısı, ezber bilgi ve tutarsız bilgi sıklıkları Tablo 5'te verilmiştir.

Tablo 5: Biyoloji Öğretmen Adaylarının Kavramsal Anlayış ve Kavram Yanılgısı Düzeyleri

\begin{tabular}{|c|c|c|c|c|c|c|c|c|c|}
\hline \multirow{2}{*}{$\begin{array}{c}\text { Madde } \\
\text { No }\end{array}$} & \multirow[t]{2}{*}{ Konu } & \multicolumn{2}{|c|}{$\begin{array}{c}\text { Kavramsal } \\
\text { Anlayış }\end{array}$} & \multicolumn{2}{|c|}{$\begin{array}{l}\text { Kavram } \\
\text { Yanılgısı } \\
\end{array}$} & \multicolumn{2}{|c|}{ Ezber Bilgi } & \multicolumn{2}{|c|}{$\begin{array}{c}\text { Tutarsiz } \\
\text { Bilgi }\end{array}$} \\
\hline & & $\mathbf{N}$ & $\%$ & $\mathbf{N}$ & $\%$ & $\mathbf{N}$ & $\%$ & $\mathbf{N}$ & $\%$ \\
\hline 1 & Canlı âlemlerinin özellikleri & 35 & 11,8 & 193 & 65,2 & 1 & 0,3 & 67 & 22,6 \\
\hline 2 & Ozmos ve difüzyon & 98 & 33,1 & 131 & 44,3 & 17 & 5,7 & 50 & 16,9 \\
\hline 3 & Prokaryot ve ökaryot hücreler & 31 & 10,5 & 185 & 62,5 & 78 & 26,4 & 2 & 0,7 \\
\hline 4 & Canlılarda üreme & 42 & 14,2 & 212 & 71,6 & 40 & 13,5 & 2 & 0,7 \\
\hline 5 & Hücre bölünmesi & 48 & 16,2 & 238 & 80,4 & 4 & 1,4 & 6 & 2,0 \\
\hline 6 & Enerji metabolizması & 148 & 50,0 & 134 & 45,3 & 10 & 3,4 & 4 & 1,4 \\
\hline 7 & Hücresel organizasyon & 109 & 36,8 & 83 & 28,0 & 97 & 32,8 & 7 & 2,4 \\
\hline 8 & Memelilerin özellikleri & 63 & 21,3 & 217 & 73,3 & 11 & 3,7 & 5 & 1,7 \\
\hline 9 & Omurgalı hayvanlar & 65 & 22,0 & 134 & 45,3 & 86 & 29,1 & 11 & 3,7 \\
\hline 10 & Üreme sistemi hormonları & 18 & 6,1 & 220 & 74,3 & 44 & 14,9 & 14 & 4,7 \\
\hline 11 & Kas ve sinir sistemi ilişkisi & 37 & 12,5 & 193 & 65,2 & 48 & 16,2 & 18 & 6,1 \\
\hline 12 & Dolaşım sistemi & 25 & 8,4 & 246 & 83,1 & 14 & 4,7 & 11 & 3,7 \\
\hline 13 & Sindirim sistemi & 29 & 9,8 & 232 & 78,4 & 19 & 6,4 & 16 & 5,4 \\
\hline 14 & Hücre solunumu & 97 & 32,8 & 177 & 59,8 & 21 & 7,1 & 1 & 0,3 \\
\hline 15 & Hücre solunumu & 108 & 36,5 & 113 & 38,2 & 53 & 17,9 & 22 & 7,4 \\
\hline 16 & Protein sentezi & 27 & 9,1 & 242 & 81,8 & 21 & 7,1 & 6 & 2,0 \\
\hline 17 & Tohum çimlenmesi & 113 & 38,2 & 169 & 57,1 & 11 & 3,7 & 3 & 1,0 \\
\hline 18 & Fotosentez & 127 & 42,9 & 44 & 14,9 & 118 & 39,9 & 7 & 2,4 \\
\hline 19 & Genetik & 56 & 18,9 & 227 & 76,7 & 0 & 0,0 & 13 & 4,4 \\
\hline 20 & Enzimler & 27 & 9,1 & 138 & 46,6 & 127 & 42,9 & 4 & 1,4 \\
\hline
\end{tabular}

Bulgular katılımcıların birçok genel biyoloji konusunda yaygın kavram yanılgılarına sahip olduklarını göstermektedir. Öğretmen adaylarının ve en düşük kavramsal anlayışa sahip oldukları konular Üreme Sistemi $(\% 6,1)$, Dolaşım sistemi $(\% 8,4)$ ve Protein sentezidir $(\% 9,1)$. Öğretmen adaylarının en yüksek kavramsal anlayışa sahip oldukları konular sırası ile enerji metabolizması $(\% 50)$, Fotosentez $(\% 42,9)$, Tohum çimlenmesi $(\% 38,2)$, Hücresel organizasyon $(\% 36,8)$ ve Hücre solunumudur $(\% 36,5)$.

Öğretmen adaylarının en az \%80'ninde kavram yanılgısı gözlenen genel biyoloji konuları dolaşım sistemi, protein sentezi ve hücre bölünmesidir. Sindirim sistemi, genetik materyal, üreme sistemi hormonları, memelilerin özellikleri ve canlılarda üreme konularında biyoloji öğretmen adaylarının \%70-80'ninde kavram yanılgısı gözlenmiştir. Katılımcıların \%60-70'inde prokaryot ve ökaryot hücre özellikleri, canlı âlemlerinin özellikleri ve kasların kasılması ve sinir sistemi ilişkisi konularında kavram yanılgısı gözlenmiştir. Hücre solunumu ile tohum çimlenmesi ile kavram yanılgılarına sahip olma oranları \%50-60 düzeyindedir. Kavram yanılgısı gözlenme oranının \%50'nin altında olan konular ise sirasıyla enzim özellikleri, enerji metabolizması, omurgalı hayvanların sınıflandırılması, ozmos ve difüzyon, hücre solunumu, hücre ve organizma arasındaki farkl1lık ve fotosentezdir. Ezber bilgi en yüksek enzim özellikleri $(\% 42,9)$, fotosentez $(\% 39,9)$, hücresel organizasyon $(\% 32,8)$, omurgal hayvanlar $(\% 29,1)$ ve prokaryot ve ökaryot hücre özellikleri $(\% 26,4)$ konularında gözlenmiştir. Tutarsız bilgi ise en çok canlı âlemlerinin özellikleri $(\% 22,6)$ ve ozmos ve difüzyon $(\% 16,9)$ konularındadır. Biyoloji öğretmenlerinde tespit edilen en önemli kavram yanılgıları Tablo 6’ta verilmiştir. 


\section{Şekil 1: Konulara Göre Kavram Yanılgısı Gözlenme Oranları}

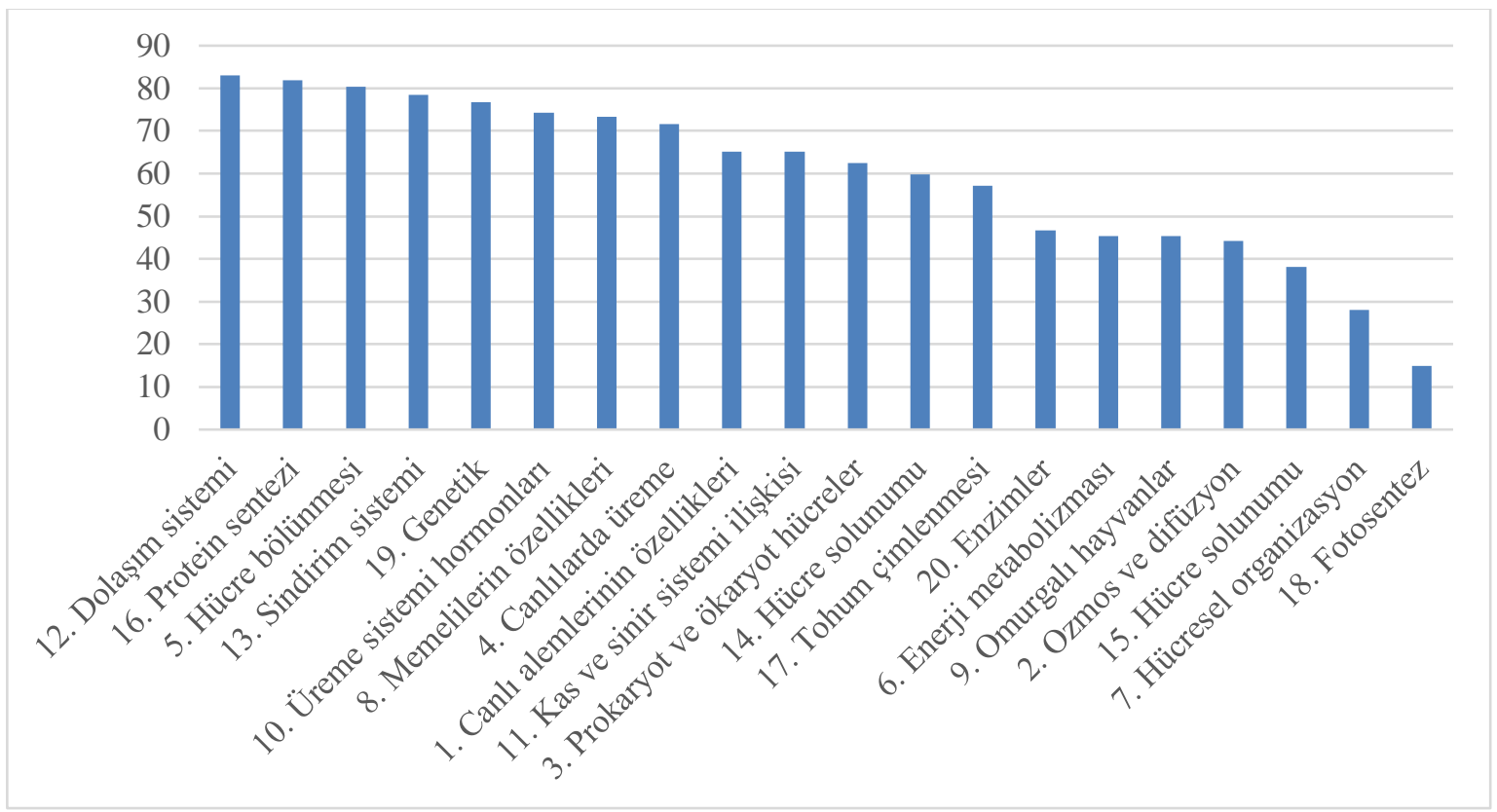

Tablo 6: Öğretmen Adaylarında En Sık Karşılaşılan Genel Biyoloji Kavram Yanılgıları

\begin{tabular}{|c|c|}
\hline $\begin{array}{l}\text { Madde } \\
\text { No }\end{array}$ & Genel biyoloji kavram yanılgısı \\
\hline 1 & Kloroplast olmadan fotosentez olmaz \\
\hline 2 & Difüzyon rastgele bir süreç olmasına rağmen, ozmos değildir \\
\hline 3 & Maya hücreleri protista âleminde sınıflandırılır \\
\hline 4 & $\begin{array}{l}\text { Erkek bal arısı partenogenez ile oluşmuş haploit bir canlı olduğu için gametlerini mitoz ile } \\
\text { oluşturur. Bitkilerde ise gamet üretimi yalnızca mayoz ile gerçekleşir }\end{array}$ \\
\hline 5 & $\begin{array}{l}\text { Hücre bölünmesi için gerekli olan enzimler ve enerji interfazda hazırlandığı için bölünme } \\
\text { sırasında bir organele ihtiyaç duyulmaz }\end{array}$ \\
\hline 6 & Yüksek enerji elde etmek için yağlar kullanılır \\
\hline 7 & Organizmalar dokulardan ve organlardan meydana gelir \\
\hline 8 & Memelilerin tümünde iç döllenme ve iç gelişme görülür \\
\hline 9 & Köpekbalıkları iç döllenme ve iç gelişme yapar. Yavru plasenta ile beslenir \\
\hline 10 & FSH seviyesinin artması mensturasyon döngüsünün başlamasını sağlar \\
\hline 11 & Motor sinirlerde uyarı iletiminin engellenmesi, uyartıların alınmasını da engeller \\
\hline 12 & İnce bağırsakta emilim ile alınan glikoz, aminoasit ve yağlar aynı şekilde taşınır \\
\hline 13 & Geviş getiren otçulların bağırsakları geviş getirmeyenlere göre daha uzundur \\
\hline 14 & Bitkiler gündüz fotosentez yapıp, gece solunum yaparlar \\
\hline 15 & Tüm organizmalar oksijene ihtiyaç duyar \\
\hline 16 & $\begin{array}{l}\text { Protein sentezinde öncelikle DNA molekülü kopyalanır ve DNA'daki bilgiler mRNA'ya yazılır. } \\
\text { Ardından m RNA'nın translasyon işlemi gerçekleşir }\end{array}$ \\
\hline 17 & Tohum canlılık özelliği göstermez \\
\hline 18 & Fotosentezde üretilen oksijen $\left(\mathrm{O}_{2}\right)$ karbondioksitin $\left(\mathrm{CO}_{2}\right)$ ayrışması ile oluşur \\
\hline 19 & Göz rengi genleri sadece eşey hücrelerinde ve göz hücrelerinde bulunur \\
\hline 20 & Substrat yüzeyinin artması reaksiyon hızını arttırır \\
\hline
\end{tabular}


Biyoloji öğretmenleri öğrencilerinin gelişmekte olan kavrayışlarında önemli etkenler olduklarından, doğru bilimsel kavramlara sahip olmaları çok önemlidir. Genel Biyoloji Yanılgıları Testi sonuçları, testin içerdiği temel kavramları öğretmek için gerekli biyolojik bilgi ve anlayışa sahip olması beklenen biyoloji öğretmenleri için yetersiz olarak görülebilir.

\section{Sonuç ve Tartışma}

$\mathrm{Bu}$ araştırmada geliştirilen Genel Biyoloji Kavram Yanılgıları Tanı Testi biyoloji öğretmenleri, öğretmen adayları ve öğrencilerinin kavram yanılgılarının tespit edilmesinde kullanılabilecek güvenilir ve geçerli bir testtir. Biyolojide kavram yanılgıları çalışmalarında her öğretim kademesinde ve her konuda kavram yanılgılarının yaygın olduğu görülmektedir. Öğretimin kalitesini arttırmak, öğrenci ihtiyaçlarına daha etkili cevap verebilmek ve doğru bilimsek kavramları anlamlı öğrenebilmenin önündeki engelleri kaldırabilmek için kavram yanılgılarının tespiti önemlidir. Bundan dolayı konunun güncelliği devam etmekte ve ilgili araştırma sayısı her geçen gün artmaktadır (Kumandaş vd, 2019; Adıgüzel vd, 2018). Çalışmanın bulguları, biyoloji öğretmen adaylarının lise programında yer alan genel biyoloji konularına ilişkin kavram yanılgılarına oldukça yüksek oranda sahip oldukları görülmektedir. Soruların içerik bölümüne verilen cevaplarda yanlış oranı daha az olmasına rağmen kavram yanılgısını tespit etmek amacıyla uygulanan ikinci adımdaki gerekçe bölümünde yapılan hatalar daha yüksektir.

Biyoloji öğretmen adaylarında yaygın gözlenen bir kavram yanılgısı üreme hormonların insan vücudundaki etkileri ile ilgilidir. Öğretmen adaylarının sadece $\% 6,1$ 'i bu konuda doğru bilimsel kavramlara sahiptir. Öğretmen adaylarının neredeyse tamamı mensturasyon döngüsünü başlatan hormonlar (östrojen ve progesteron) ile ilgili bilmemektedir. Yanlış olarak bilinen ise mensturasyon döngüsünü başlatan hormonun FSH olduğudur. Bernhisel (1999) tarafından yapılan benzer bir çalışmada, biyoloji öğretmen adaylarının \%39,4'ü soruya doğru cevap vermiştir. Enzimlerin özellikleri konusunda öğretmen adaylarının yarısı içerik bilgisine sahip olmasına rağmen süreç ile ilgili doğru gerekçeyi belirleyememiştir. Replikasyon, transkripsiyon ve translasyon süreçleri ve protein sentezi ile ilişkileri anlayışları da sorunludur. Protein sentezinin transkripsiyon ve translasyon işlemlerinden oluştuğu, replikasyonun ise bu süreç ile ilgili olmadığı katılımcıların sadece \%9,1'i tarafindan doğru ifade edilmiştir. Benzer şekilde, Deveci (2019) biyoloji öğretmen adayları üzerinde yaptığı çalışmada protein sentezi konusunda kavram yanılgılarının tespit etmiştir.

Biyoloji öğretmen adayları ince bağırsakta emilen karbonhidrat, protein ve yağların vücuda farklı şekillerde nasıl yayıldıklarını anlamamıştır. Katılımcıların sadece \%8,4'ü yağ asitleri ve A vitaminini izlediği yolu doğru cevaplamıştır. Katılımcıların sadece \%11,8'i "kloroplast organelinin fotosentez yapabildikleri için hem tek hücreli hem de çok hücreli canlılarda bulunduğunu" doğru cevabını vermiştir. $\mathrm{Bu}$ araştırmanın sonuçlarına benzer biçimde fotosentezin sadece bitkilerde olduğu kavram yanılgısı, farklı araştırmalarda hem öğretmen adayları hem de lise öğrencileri tarafından paylaşıldığı tespit edilmiştir. Tekkaya ve Balcı (2003) tarafından yapılan çalışmada, 9. sinıf öğrencilerinin \%92'si, 10. sinıf öğrencilerinin \%93'ü ve 11. sinıf öğrencilerin \%54'ü sadece bitkilerin fotosentez yaptı̆̆ını ifade etmiştir. Katılımcıların duyu, motor ve ara nöronların işlevleri, uyartıların alınması ve bunlara karşı tepki verilmesi sürecini anlamadıkları görülmüşsür. Canlılarda üreme konusundaki kavram yanılgılarını ölçmek için yöneltilen soruya öğretmen adaylarının $\% 14,2$ 'si doğru cevabı vermişlerdir. Mitoz ve mayoz bölünme, öğretmen adaylarında ve öğrencilerde yaygın olarak kavram yanılgılarının olduğu bir konudur. Özcan vd. (2012) ve Çakır ve Aldemir (2011) biyoloji öğretmen adaylarında mitoz ve mayoz bölünmesinin safhaları ile özellikleri konularında çok fazla kavram yanılgısı tespit edilmiştir. Emre ve Bahşi (2006) tarafindan fen bilgisi öğretmen adaylarında "mayoz bölünmeye bitkilerde rastlanmaz (\% 61)", kavram yanılgısı tespit edilmiştir. Atılboz'un (2004) lise 9. sınıf öğrencilerinde bu çalışmada elde edilen bulgulara benzer kavram yanılgıları tespit edilmiş̧ir. Dokuzuncu sınıf (Kara, 2007; Yeşilyurt ve Kara, 2007) ve sekizinci sınıf (Aydın ve Balım, 2013) öğrencileri üzerinde yapılan benzer çalışmalarda da 
öğrencilerin mitoz ve mayoz bölünme konusunda çok sayıda kavram yanılgısı taşıdıkları tespit edilmiştir.

Öğretmen adaylarının memeli hayvanların ortak özellikleri konusundaki kavram yanılgıları ölçülmüştür. Benzer șekilde, Çardak (2009) öğretmen adaylarının canların sınıflandırması konusundaki kavram yanılgılarını belirlediği çalışmasında, kuşlar, memeliler ve balıkları birbirinden ayıran genel özelliklerde kavram yanılgıları tespit etmiştir. Canlılar konusundaki genel ayrıma ilişkin kavram yanılgıları lise öğrencilerinde de gözlenmektedir (Naz ve Nasreen, 2013; Kubiatko ve Prokop, 2007-2009).

Öğretmen adaylarının hücre solunumu konusundaki kavram yanılgıları iki soru ile tespit edilmiştir. Bitkilerin gündüz fotosentez yapıp, gece solunum yaptıkları sanılmaktadır. Bu sonuca göre öğretmen adaylarının bitkilerde solunum konusunda literatürde de yaygın olarak görülen kavram yanılgılarına sahip oldukları görülmektedir. Benzer sonuçların elde edildiği çok sayıda araştırma mevcuttur. Krall vd. (2009) çalışmalarında öğretmenlerin yüzde 75'inin solunum için 1şığa ihtiyaç olmadığını bilmediklerini tespit etmişlerdir. Çokadar (2012), öğretmen adaylarında fotosentez ve solunum süreçleri konusundaki çok sayıda kavram yanılgısı tespit etmiştir. Solunum ve fotosentez konusunda ortaokul ve lise ögrencilerinde de benzer kavram yanılgıları tespit edilmiştir. Öğrencilerde kavram yanılgısı oranları daha yüksektir (Aşçı vd., 2001; Tekkaya ve Balcı, 2003; Svandova, 2014; Karagöz, 2016). Solunum konusundaki ikinci soruda ise biyoloji öğretmen adaylarının \%36,5'i "bütün canlılar enerji ihtiyacı için hücresel solunum yaparlar" doğru cevabını vermiş̧lerdir. Bu konudaki temel kavram yanılgısı, hücresel solunumun oksijen ihtiyacı için yapıldığının sanılmasıdır. Sonuçlara bakıldığında öğretmen adaylarının yarısının hücresel solunumu hangi canlıların neden yaptıklarını bilmedikleri, bununla ilgili kavram yanılgılarına sahip oldukları söylenebilir. Hücresel solunum zor ve kavram yanılgılarının çok olduğu bir konudur (Finley vd., 1982; Stavy vd., 1987). Öğretmen, öğretmen adayları ve öğrenciler üzerinde yapılan çalışmalarda bu konuda yaygın kavram yanılgıları tespit edilmiştir (Stavy vd., 1987; Wandersee 1983; Marmaroti ve Galanopoulou, 2006; Tekkaya ve Balc1, 2003; Çokadar, 2012; Svandova, 2014; Krall vd., 2009). Üniversite öğrencileri üzerinde yapılan bir çalışmada öğrencilerin yüzde 25'inin solunumun amacını bilmedikleri tespit edilmiştir (Aşçı vd., 2001).

Araştırma bulgularına göre öğretmen adaylarının \%32,8'i "hücre canlı olmasa da osmoz ve difüzyonun devam ettiğini” doğru olarak bilmiştir. Öğretmen adayları, ölü hücrede sadece difüzyonun devam edeceği, çünkü difüzyonun rastgele olduğu kavram yanılgısını taşımaktadır. Öğrenciler üzerinde yapılan çalışmalardan bu konuda yaygın bir kavram yanılgısı olduğu anlaşılıyor. Koyuncuer'in (2014) lise 9. sınıf öğrencileri üzerinde yaptığı çalışmada, öğrencilerin tamamına yakını difüzyon ve osmozun sadece canlı hücrelerde meydana geldiğini belirtmiştir. Yine 9. sınıf öğrencileri üzerinde yapılan diğer bir çalışmada öğrencilerin yarısının benzer bir kavram yanılgıya sahip oldukları tespit edilmiştir (Odom, 1995). Öğretmen adaylarının yarısından fazlasının fotosentez ve solunum konusunda tohum ve bitki arasındaki farkı bilmemektedir. Öğretmen adayları tohumun neden fotosentez yapmadığı konusunda kavram yanılgılarına sahiptir. Tohum canlı değildir, solunum için fotosentez gereklidir gibi kavram yanılgıları vardır. Krall vd. (2009) biyoloji öğretmenlerinin yarısının tohum ve bitkinin ihtiyaçları arasındaki farkı bilemediklerini tespit etmiştir. Fotosentez ile ilgili bir diğer kavram yanılgısı, fotosentez sonucu ortaya çıkan oksijen gazının kaynağıdır. Öğretmen adayları oksijenin karbondioksit gazının ayrışması sonucu oluştuğunu düşünmektedir. Hâlbuki fotosentezde oluşan oksijenin kaynağ 1 sudur. Oksijenin karbondioksitten oluştuğu kavram yanılgısı öğretmen adayları ve öğrencilerde oldukça yaygındır. Çokadar (2012)'ın öğretmen adayları üzerinde yaptığı araştırmada belirtilen kavram yanılgısını tespit etmiștir. Kırılmazkaya ve Zengin (2016) fen bilgi öğretmen adaylarının fotosentez konusunda kavram yanılgılarının olduğunu tespit etmiştir. Fotosentez konusundaki kavram yanılgısı düzeyi oldukça düşük çıkmıştır. Tekkaya ve Balcı 
(2003) tarafından yapılan çalışmada lise öğrencilerinin \%90'ının aynı kavram yanılgısına sahip oldukları tespit edilmiştir.

\section{Öneriler}

En az dört yıl biyoloji eğitimi alan öğretmen adaylarında genel biyoloji konularında bu kadar çok bilgi eksikliği ve kavram yanılgısının bulunması, öğretmen eğitimi veren yükseköğretim kurumlarının ders içeriklerini ve kalitelerini sorgulamalarını gerektirir. Öğretmen eğitimi veren yükseköğretim kurumları kavram yanılgılarının giderilmesine özel önem vermelidir. Fakültelerde alan derslerinde bu araştırmada geliştirilen Genel Biyoloji Kavram Yanılgıları Tanı Testi yardımı ile biyoloji öğretmen adayları ve öğrencilerinin kavram yanılgıları tespit edilebilir ve sonuçlara uygun bir öğretim tasarlanabilir. Özellikle lise konularının olduğu genel biyoloji konularında öğretmen adaylarındaki kavram yanılgıları üzerinde daha ayrıntılı durulmalıdır. Öğretmen adaylarının kavram yanılgısına sahip olmaları belirli bir süre sonra bu yanılgıları lise öğrencilerine yansımasına sebep olacaktır. Kavram yanılgılarının temel kaynaklarından birisinin öğretmenler olması bu kaygıyı desteklemektedir. Öğretmen adaylarına kavram yanılgılarının farkına varmaları için bu çalışmada kullanılan tarzda kavram yanılgı testleri uygulanabilir. Böylece kişi kendisindeki kavram yanılgılarının farkına varır ve düzeltme yolunda gayret gösterir. Buna ek olarak öğretmen sorumlukları da hatırlatılmalı, kendi yanlışlarının başkalarına geçmesinden sorumlu olacakları vurgulanmalıdır. Bu sayede kavram yanılgılarını düzeltme adına daha fazla motive olacaklardır.

\section{Kaynakça}

Adıgüzel, T., Şimşir, F., Çubukluöz, Ö., \& Özdemir, B. G. (2018). Türkiye'de matematik ve fen eğitiminde kavram yanılgılarıyla ilgili yapılan yüksek lisans ve doktora tezleri: Tematik bir inceleme. Bayburt Ë̆itim Fakültesi Dergisi, 13(25), 57-92. https://doi.org/10.17680/erciyesakademia.291891

Arsal, Z. (2010). The greenhouse effect misconceptions of the elementary school teacher candidates. Elementary Education Online, 9(1), 229-240.

Aşçı, Z., Özkan, Ş., \& Tekkaya, C. (2001). Öğrencilerin solunum konusundaki kavram yanılgıları: karşılaştırmalı bir çalışma. Eğitim ve Bilim, 26(120), 29-36.

Atılboz, N. G. (2004). Lise 1. sınıf öğrencilerinin mitoz ve mayoz bölünme konuları ile ilgili anlama düzeyleri ve kavram yanılgıları. Gazi Üniversitesi Gazi Eğitim Fakültesi Dergisi, 24(3), 147157. https://doi.org/10.17152/gefad.439037

Aydın, G., \& Balım, A. G. (2013). Öğrencilerin "hücre bölünmesi ve kalıtım” konularına ilişkin kavram yanılgıları. Eğitim ve Ö̆gretim Araştırmaları Dergisi, 2(1), 338-348.

Bahar, M. (2003). Biyoloji eğitiminde kavram yanılgıları ve kavram değişim stratejileri. Kuram ve Uygulamada Eğitim Bilimleri, 3(1), 27-64. https://doi.org/10.17244/eku.310220

Baykul, Y. (2015). Eğitimde ve psikolojide ölçme: Klasik test teorisi ve uygulaması. Pegem Akademi Yayıncilik.

Bernhisel, S. M. (1999). Measuring preservice and inservice biology teachers' understanding of selected biological concepts, [Doctoral Dissertation, Utah State University].

Bretz, S. L., \& Linenberger, K. J. (2012). Development of the enzyme-substrate interactions concept inventory. Biochemistry and Molecular Biology Education, 40(4), 229-233. https://doi.org/10.1002/bmb.20622

Büyüköztürk, Ş., Çakmak, E. K., Akgün, Ö. E., Karadeniz, Ş., \& Demirel, F. (2016). Bilimsel araştırma yöntemleri. Pegem Akademi. https://doi.org/10.14527/9789944919289 
Chandrasegaran, A. L., Treagust, D. F., \& Mocerino, M. (2007). The development of a two-tier multiple-choice diagnostic instrument for evaluating secondary school students' ability to describe and explain chemical reactions using multiple levels of representation. Chemistry Education Research and Practice, 8(3), 293-307. https://doi.org/10.1039/b7rp90006f

Coştu, B., Ayas, A., \& Ünal, S. (2007). Kavram yanılgıları ve olası nedenleri: Kaynama kavramı. Kastamonu Eğitim Dergisi, 15(1), 123 - 136.

Çakır, M. (2008). Constructivist approaches to learning in science and their implications for science pedagogy: A literature review. International Journal of Environmental and Science Education, 3(4), 193-206.

Çakır, M. ve Aldemir, B. (2011). İki aşamalı genetik kavramlar tanı testi geliştirme ve geçerlik çalışması. Mustafa Kemal Üniversitesi Sosyal Bilimler Enstitüsü Dergisi, 8(16), 335-353.

Çardak, O. (2009). Science students' misconceptions about birds. Scientific Research and Essay, 4(12), 1518-1522.

Çokadar, H. (2012). Photosynthesis and respiration processes: prospective teachers' conception levels. Education \& Science/Egitim ve Bilim, 37(164), 82-94.

Deveci, E. (2019). Biyoloji ögrretmen adaylarının protein sentezi konusundaki teknolojik pedagojik alan bilgisi [Yüksek Lisan Tezi, Hacettepe Üniversitesi]. https://doi.org/10.17679/inuefd.566462

Ecevit, T., \& Şimşek, P. Ö. (2017). Öğretmenlerin fen kavram öğretimleri, kavram yanılgılarını saptama ve giderme çalışmalarının değerlendirilmesi. İlköğretim Online, 16(1), 129-150. https://doi.org/10.17051/io.2017.47449

Emre, İ., \& Bahşi, M. (2006). Fen bilgisi öğretmen adaylarının hücre bölünmesiyle ilgili kavram yanılgıları. Doğu Anadolu Bölge Araştırmaları (DAUM), 4(3), 70-73. https://doi.org/10.25092/baunfbed.366219

Finley, F. N., Stewart, J., \& Yarroch, W. L. (1982). Teachers' perceptions of important and difficult science content. Science education, 66(4), 531-538. https://doi.org/10.1002/sce.3730660404

Gooding, J., \& Metz, B. (2011). From misconceptions to conceptual change. The Science Teacher, 78(4), 34-37.

Hershey, D. R. (2004). Avoid misconceptions when teaching about plants. http://www.actionbioscience.org/education/hershey.html https://doi.org/10.14527/9786053186496.14

Kara, Y. (2007). Mitoz ve mayoz bölünme konularında öğrenci başarıları, kavram yanılgıları ve biyolojiye karşı tutumlara öğretim amaçlı bilgisayar yazılımların etkisi. Dokuz Eylül Üniversitesi Buca Eğitim Fakültesi Dergisi, 21(2007), 49-57. https://doi.org/10.18613/deudfd.07978

Karagöz, S. (2016). Lise 11. sınıf biyoloji dersinde fotosentezde kavram yanılgıları [Yüksek Lisans Tezi, Necmettin Erbakakan Üniversitesi].

Kaya, F. (2010). Fen bilgisi öğretmen adaylarında fotosentez ve bitkilerde solunum konularında görülen kavram yanılgılarının giderilmesinde bilgisayar destekli kavramsal değişim metinlerinin etkisi [Yüksek Lisans Tezi, Pamukkale Üniversitesi]. https://doi.org/10.16986/huje.2019052442 
Kete, R., Horasan, Y., \& Namdar, B. (2012). Investigation of the conceptual understanding difficulties in 9th grade biology books about cell unit. Elementary Education Online, 11(1), 95-106.

Khalid, T. (2001). Pre-service teachers' misconceptions regarding three environmental issues. Canadian Journal of Environmental Education (CJEE), 6(1), 102-120.

Kırılmazkaya, G., \& Zengin, F. K. (2016). Öğretmen adayları fotosentez konusu hakkında kavram yanılgılarının vee diyagramı aracılığıyla belirlenmesi ve bu araca yönelik görüşlerinin tespiti. Erzincan Üniversitesi Ë̆itim Fakültesi Dergisi, 18(2), 1537-1563. https://doi.org/10.14582/duzgef.645

Koyuncuer (2014). Lise 9. sinıf ögrencilerin difüzyon ve ozmos ile ilgili kavram yanılgıları [Yüksek Lisans Tezi, Necmettin Erbakakan Üniversitesi].

Krall, R. M., Lott, K. H., \& Wymer, C. L. (2009). Inservice elementary and middle school teachers' conceptions of photosynthesis and respiration. Journal of Science Teacher Education, 20(1), 41-55. https://doi.org/10.1007/s10972-008-9117-4

Kubiatko, M., \& Prokop, P. (2009). Pupils' understanding of mammals: An investigation of the cognitive dimension of misconceptions. Orbis Scholae, 3(2), 97-112.

Kubiatko, M., \& Prokop, P. (2007). Pupils' misconceptions about mammals. Journal of Baltic Science Education, 6(1), 5-14. https://doi.org/10.14712/23363177.2018.214

Kumandaş, B., Ateskan, A., \& Lane, J. (2019). Misconceptions in biology: a meta-synthesis study of research, 2000-2014. Journal of Biological Education, 53(4), 350-364. https://doi.org/10.1080/00219266.2018.1490798

Kurt, H. (2013). Biyoloji öğretmen adaylarının "enzim" konusundaki bilişsel yapılarının belirlenmesi. Gazi University Journal of Gazi Educational Faculty (GUJGEF), 33(2), 211243. https://doi.org/10.17152/gefad.43887

Malatyalı, E., \& Y1lmaz, K. (2010). Yapılandırmacı öğrenme sürecinde kavramlar ve önemi: Kavramların pedagojik açıdan incelenmesi. Uluslararası Sosyal Araştırmalar Dergisi, 3(14), 320-332.

Marmaroti, P., \& Galanopoulou, D. (2006). Pupils' understanding of photosynthesis: A questionnaire for the simultaneous assessment of all aspects. International Journal of Science Education, 28(4), 383-403. https://doi.org/10.1080/09500690500277805

Nakiboğlu, C. (2006). Fen ve teknoloji öğretiminde yanlış kavramalar. İçinde B.Mehmet (Ed.), Fen ve teknoloji ögretimi (ss.191-217). Pegema Yayıncılık.

Naz, A., \& Nasreen, A. (2013). An Exploration of students' misconceptions about the concept'classification of animals' at secondary level and effectiveness of inquiry method for conceptual change. Eğitim Bilimleri Fakültesi Dergisi, 46(2), 195-214. https://doi.org/10.1501/egifak_0000001301

Nunally J., (1978). Psychometric theory (2nd ed.). McGraw Hill.

Odom, A. L. (1995). Secondary \& college biology students' misconceptions about diffusion \& osmosis. The American Biology Teacher, 57(7), 409-415. https://doi.org/10.2307/4450030

Özcan, T., Yıldırım, O., \& Özgur, S. (2012). Determining of the university freshmen students' misconceptions and alternative conceptions about mitosis and meiosis. Procedia-Social and Behavioral Sciences, 46 (2012), 3677-3680. https://doi.org/10.1016/j.sbspro.2012.06.126 
Özgür, S. (2013). The persistence of misconceptions about the human blood circulatory system among students in different grade levels. International Journal of Environmental and Science Education, 8(2), 255-268. https://doi.org/10.12973/ijese.2013.206a

Pelaez, N. J., Boyd, D. D., Rojas, J. B., \& Hoover, M. A. (2005). Prevalence of blood circulation misconceptions among prospective elementary teachers. Advances in Physiology Education, 29(3), 172-181. https://doi.org/10.1152/advan.00022.2004

Riche, R. D. (2000). Strategies for assisting students overcome their misconceptions in high school physics. Memorial University of Newfoundland Education, 6390.

Selvi, M. ve Yakışan, M. (2004). Üniversite birinci sınıf öğrencilerinin enzimler konusu ile ilgili kavram yanılgıları. Gazi Eğitim Fakültesi Dergisi, 24 (2), 173-182. https://doi.org/10.14582/duzgef.520

Stavy, R., Eisen, Y. \& Yaakobi, D. (1987). How students ages 13-15 understand photosynthesis. International Journal of Science Education, 9(1), 105-115. https://doi.org/10.1080/0950069870090111

Svandova, K. (2014). Secondary school students' misconceptions about photosynthesis and plant respiration: Preliminary results. Eurasia Journal of Mathematics, Science \& Technology Education, 10(1), 59-67. https://doi.org/10.12973/eurasia.2014.1018a

Tekkaya, C. (2002). Misconceptions as barrier to understanding biology. Hacettepe Üniversitesi Eğitim Fakültesi Dergisi, 23(23), 259-266.

Tekkaya, C., \& Balcı, S. (2003). Öğrencilerin fotosentez ve bitkilerde solunum konularındaki kavram yanılgılarının saptanması. Hacettepe Üniversitesi Ĕgitim Fakültesi Dergisi, 24(24), 101-107. https://doi.org/10.14686/buefad.308999

Tekkaya, C., Çapa, Y., \& Yılmaz, Ö. (2000). Biyoloji öğretmen adaylarının genel biyoloji konularındaki kavram yanılgıları. Hacettepe Universitesi Ĕ̈itim Fakültesi Dergisi, 18(18). https://doi.org/10.17522/balikesirnef.373344

Treagust, D. F. (1998). Development and use of diagnostic tests to evaluate students' misconceptions in science. International Joumal of Science Education, 10(2), 159-169. https://doi.org/10.1080/0950069880100204

Turgut, M. F., \& Baykul, Y. (2015). Eğitimde ölçme ve değerlendirme (Yedinci Baski). Pegem A Yayınc1lik. https://doi.org/10.14527/9786053640875

Wandersee, J. H. (1983). Students' misconceptions about photosynthesis: A cross-age study. In H. Helm \& J. D. Novak (Eds.), Proceedings of the international seminar "Misconceptions in science and mathematics"' (pp. 441-466). Cornell University (ED242553).

Yeşilyurt, S., \& Kara, Y. (2007). The effects of tutorial and edutainment software programs on students'achievements, misconceptions and attitudes towards biology on the cell division 1ssue. Journal of Baltic Science Education, 6(2), 5-15. https://doi.org/10.1007/s10956-0079077-z 